\title{
Godkendelsesfælder \\ i BA-projekt- og specialevejledning
}

Thomas Harboe, centerleder, Pedagogisk Center, Samfundsvidenskab, Kobenhavns Universitet.

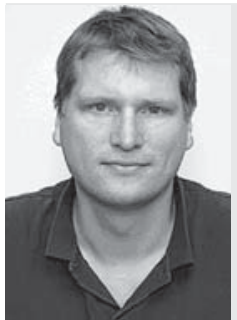

Thomas Harboe er uddannet cand. mag. (filosofi) fra Københavns Universitet suppleret med en master i pædagogisk udviklingsarbejde fra Danmarks Pædagogiske Universitet. Thomas Harboes primære arbejdsområder er pædagogisk udvikling, vejledning, metode, studieteknik, skriveprocesser m.m. Han er (med-)forfatter til flere bøger, hæfter og rapporter inden for universitetspædagogik. Thomas Harboe er formand for DUN.

\section{Reviewet artikel}

Specialevejledningen har lange varet et omrade inden for universitetspadagogikken, der levede bag lukkede dore. Målrettede evalueringer og forskellige undersøgelser inden for de seneste àr forsøger at råde bod på dette, og $i$ dag findes der et bedre grundlag for en videnbaseret debat om specialevejledningen. I jagten på ny viden om specialevejledning har jeg gennemlast 51 klagesager og fandt $i$ dette materiale en udtalt forventning hos de studerende om godkendelse (blastempling) for aflevering. Jeg vil $i$ denne artikel presentere tre typiske godkendelsesfaelder, som jeg fandt udtrykt i klagesagerne. Falles for alle tre godkendelsesfaclder er, at den endelige bedømmelse spiller en uforholdsmassig stor rolle gennem hele vejledningsforløbet hos de studerende, og en losning kan derfor vare at adskille vejledning og bedommelse ved det afsluttende speciale.

\section{Materiale og metode}

Min undersøgelse, der blev gennemført og afleveret som masterprojekt på DPU i foråret 2005, bygger på en gennemlæsning af 51 klagesager samt afholdelsen af en fokusgruppe. De 51 klagesager dækker den totale population af klagesager inden for rammerne af Eksamensbekendtgørelsen $\$ 37$ og $\$ 40$ med relation til BAprojekter og specialer på Det Samfundsvidenskabelige Fakultet, KU, samt DPU i kalenderåret 2004.

I hver klagesag ligger al formel og skriftlig kom- munikation i forbindelse med klagen - dvs. den studerendes klage, vejleders og censors fælles klagesvar og eventuelle anker og ankeafgørelser. Derimod rummer klagesagerne ikke den mere uformelle og mundtlige kommunikation, der måtte have fundet sted mellem de involverede parter.

Selvom de studerende formelt set ikke kan klage over vejleder og vejledningsforløbet inden for Eksamensbekendtgørelsens rammer, sker dette i lidt over halvdelen af klagesagerne. Klagesagerne kan derfor fint bruges til at åbne dørene til et ellers privat og lukket vejledningsrum - og om muligt formulere handlingsforslag til en kvalitetsudvikling af vejledningen. Selve undersøgelsen var en eksplorativ og elaborativ gennemlæsning af klagesagerne, og de tre godkendelsesfælder, der bliver præsenteret i denne artikel, er således vokset frem gennem læsningen af klagesagerne og var ikke formuleret på forhånd.

Ved læsningen af klagesagerne fik jeg blik for seriøsiteten i de fleste klagesager, hvad enten de var rimelige eller ej. De studerende gør sig umage med at formulere deres klager, og de konkrete beskrivelser i klagerne er ofte ganske overbevisende for en udenforstående læser.

Omvendt er klagesagerne ikke overraskende en særlig slags subjektiv kilde om vejledning, som skal læses med et vågent blik for de bagvedliggende interesser fra de studerendes, vejleders og censors sider. Her er det en fordel at være en udenforstående læser uden egeninteresser i de specifikke klager. Men alene at basere undersøgelsens konklusioner på klagesagernes beskrivelser er i sagens natur metodisk problematisk, og jeg supplerede derfor gennemlæsningen af klagesagerne med et fokusgruppeinterview med deltagelse af to studerende og to vejledere udvalgt fra to eksemplariske klagesager. Fokusgruppen varede cirka to timer og blev efterfølgende transkriberet på baggrund af en videooptagelse.

Et andet metodisk problem er generaliserbarheden. Alene det faktum, at klagesager hører til sjældenhederne, gør, at min undersøgelse ikke kan læses som en 
generel evaluering af vejledningens kvalitet eller af de studerendes evne til at bruge vejledningstilbuddet. Ud af de 51 klagesager havde 32 relation til specialer på Samfundsvidenskab, KU, og DPU, hvilket svarer til lidt over 2 procent af den samlede kandidatproduktion på de to institutioner. De resterende 19 klagesager havde relation til BA-projekter på Samfundsvidenskab, KU (DPU har ikke en bacheloruddannelse), hvilket svarer til 4,9 procent af bachelorproduktionen i 2004.

Teoretisk koblede jeg min læsning af klagesagerne sammen med en diskussion af Anthony Giddens' begreb om tillid (Giddens, 1997) og Ralf Pittelkows tidsåndanalyse (Pittelkow, 2001). Begge beskriver de tillidsmekanismer, som senmoderne studerende forventer af universitetssystemet.

Fokus i denne artikel er at præsentere undersøgelsens empiriske resultater (dvs. de tre godkendelsesfælder) og knytte disse til en diskussion af mulige løsningsmodeller. Interesserede kan frit rekvirere min rapport for at læse de mere teoretiske aspekter af undersøgelsen.

\section{Vejleder har godkendt (dele af) projektet før aflevering}

Den første godkendelsesfælde ses i de tilfælde, hvor den studerende oplever, at eksamen/bedømmelsen kritiserer projektet for noget, som vejleder enten har godkendt eller foreslået undervejs i vejledningsforløbet. Her er tre typiske eksempler på, hvad de studerende skriver i en klage:

"Specialet blev ikke vurderet ud fra de opstillede formål og prioriteringer, som var indgående drøftet og aftalt med vejleder.« (Speciale, KU)

"Er dette tilfældet, mener jeg, at vejleder burde have nævnt denne problemstilling i forbindelse med godkendelsen af problemformuleringen og ikke først på nuværende tidspunkt.« (BA-projekt, KU)

"Jeg beklager naturligvis i dag, at jeg indlod mig på at gennemføre specialet med en anden form end den, som er den velkendte »opskrift«, og som jeg i min selvformulerede opgave også har demonstreret at kunne. Men med vejleders godkendelse og forhåndsaccept af siderne 33-37 følte jeg mig sikker på, at det var i orden." (Speciale, DPU)

Problemet her er, at vældig mange studerende tager vejleders råd og vejledninger for mere, end de reelt er, og bogstaveligt tolker dem som bindende kontrakter og blåstemplinger fra vejlederens side af de formuleringer, der en mere eller mindre tilfældig dato står på papir. En studerende formulerer dette således:

"De råd og den vejledning, som man får af vejlederen i løbet af en vejledningsproces, antager jeg, at man må tage for gode varer, for ellers er der vel ikke meget værdi at hente $i$ et vejledningsforløb for den studerende. En efterfølgende revurdering af egne råd fra vejlederens side mener jeg ikke skal kunne indgå i vurderingsgrundlaget for mit speciale. Vejlederen skal derimod stå til ansvar for de råd og den vejledning, som vedkommende har givet, og ikke bare efterfølgende klandre den studerende for at have fulgt rådene." (Speciale, KU)

Ved første øjekast kan den pågældende studerende have ret $i$, at vejleder ikke kan vejlede den studerende til hvad som helst, og at vejleders råd i en eller anden udstrækning forpligter vejleder ved den endelige bedømmelse. Det virker fx urimeligt, når censor eller vejleder ved den endelige bedømmelse kritiserer specialer for en ufrugtbar problemformulering eller for tyndt litteraturgrundlag, idet man må antage, at vejleder eksplicit har forholdt sig til disse dele undervejs i vejledningsforløbet.

Men tænker man dybere over det, er det straks mere kompliceret. Hvad skal vejleder fx svare, når den studerende spørger, om X er »tilstrcekkeligt belyst $i$ den fremsendte tekst ", eller om Y er »den rette struktur på opgaven«? På den ene side kan den studerende med rimelighed forvente, at vejleder tager stilling til sådanne spørgsmål, og det er ikke en urimelig forventning, at vejleder i tide korrigerer studerende, der tydeligt er på galt spor. På den anden side er en godkendelse problematisk, hvis der med godkendelse menes en eller anden form for fastlåsende og forpligtende garanti, ikke mindst fordi det, som isoleret set virker fornuftigt på et givet tidspunkt, kan virke forkert på et senere tidspunkt.

\section{Vejleder har undladt at rejse kritikken $i$ tide}

Den anden godkendelsesfælde er de tilfælde, hvor den studerende oplever, at specialet ved bedømmelsen bliver kritiseret for noget, som vejleder burde have advaret om undervejs i forløbet. Her er et par typiske eksempler på de studerendes klager:

»Hvis specialet som helhed lider af en »konstruktionsfejl« som f.eks. i form af en upræcis problemformulering eller en for bred emnebeskrivelse, burde dette vel være påpeget tidligere i vejledningsforløbet.«(Speciale, KU)

»Den eksterne censor nævnte også, at mit speciales litteraturliste adskiller sig fra, hvad standard er. Dog oplyste den eksterne censor mig ikke om, på hvilke punkter litteraturlisten afviger. Desuden har min vejleder ikke fremsat nogen indvendinger mod litteraturlisten under min vejledning.«(Speciale, KU) 
Pointen er her, at en stiltiende accept af at vejlede trods fundamentale problemer også kan opfattes som en slags godkendelse. Vejledere, der uden forbehold accepterer (godkender) at vejlede specialer med en fx håbløst forældet empiri eller ufrugtbare metoder/teorier, pådrager sig i de fleste studerendes øjne et medansvar for den dårlige bedømmelse. Grænsefladerne mellem "godkendelse" og "det at ikke have rejst en kritik i tide" er således ikke distinkte.

Men hvorfor har vejleder tilsyneladende undladt at sige fra undervejs? Er det et udslag af konfliktskyhed hos vejleder? Eller er det udtryk for, at vejleder er uengageret i opgaven og ikke læser teksterne ordentligt? Eller er vejleder ikke fagligt klædt på til opgaven og overser derfor indlysende fejl og mangler i opgaveudkastet? Eller hvad?

Der kan være mange forklaringer, men konfliktskyhed er antageligt ikke et ukendt fænomen blandt vejledere. For vejleder kan det være svært eller direkte ubehageligt at fortælle en studerende, at det arbejde, han eller hun har udført, er af ringe kvalitet eller endda kassabelt. Rådet til vejleder er at gøre det klart for den studerende, at der er grader af negativ kritik og herunder angive, hvor alvorlig og væsentlig kritikken er - især med henblik på hvordan den studerende kan komme videre. Hvad skal den studerende konkret gøre? Rette, omskrive, nyskrive, opgive?

\section{Vejleder har udtrykt ros undervejs i vejledningsforløb}

Den tredje godkendelsesfælde er de tilfælde, hvor den studerende oplever, at vejleder undervejs har rost specialet og derfor ikke kan forstå den lave karakterbedømmelse. Der er i flere af sådanne klagesager vedlagt udskrifter af mail-korrespondance, hvor vejleder eksplicit har udtrykt ros. Eksempelvis skriver en studerende, der har fået sit speciale bedømt til 6:

"Efter flere gennemskrivninger fik jeg både mundtlige og skriftlige kommentarer fra min vejleder, der roste opgaven (se vedlagte mails $1+2$ ).« (Speciale, KU)

I den vedlagte mailkorrespondance kan man blandt andet læse, at vejleder skriver:

"Nu har jeg læst det hele. Som sagt er det blevet meget bedre, klarere og mere stringent, og dette gør, at det er nemmere at læse og følge." (Mail fra vejleder vedhæftet i ovennævnte klagesag, speciale, KU)

En anden klagesag viser, hvordan uargumenteret ros kan give den studerende illusionen om en høj bedømmelse og en sikker fremtid:

»Vejleder opfordrede mig til at indsende en ph.d.ansøgning, som han gerne ville hjælpe med at skrive og opfordrede mig kraftigt til at indlevere specialet. (...) Han fortalte, at mit speciale var så "fint«, at jeg roligt kunne indlevere det til bedømmelse." (Speciale, KU (det færdige speciale blev bedømt til 7)).

Eksemplerne fra sådanne klagesager illustrerer det, som enhver vejleder frygter, nemlig at blive "hængt op på» ros der er givet undervejs, men som ved bedømmelsen ikke viser sig at kunne holde. Det er mit indtryk, at mange vejledere er bevidste om dette og forsøger at styre uden om denne godkendelsesfælde ved helt at undlade at rose eller komme med positive vurderinger. Dette er trist, fordi anerkendelse er et væsentligt motiverende element i enhver feedback. Ros fra vejleder kan være et konstruktivt redskab, der er med til at opbygge en faglig selvfølelse hos den studerende og skærpe det gode, den studerende allerede gør.

Rådet til vejlederen er fortsat at rose, men samtidigt gøre klart for de studerende, at hvis man roser noget, er det ikke et løfte om en tocifret karakter: Hele teksten vil blive set i sin totale kontekst og typisk sammen med en censor. Men vejleder bliver i øvrigt næppe så let hængt op på sin respons, hvis den er lokaliseret til bestemte tekstbidder i den revisionsudgave, disse foreligger $\mathrm{i}$ og hvis responsen i øvrigt tydeligt er koblet til almene tekstkriterier. En vejleder kan fx godt rose et afsnit $i$ en tekst, mens han eller hun forholder sig kritisk til andre.Vejlederen kan også rose et førsteudkast og være mere kritisk over for senere udkast.

\section{Andre undersøgelser}

Andre undersøgelser bekræfter, at godkendelse er et væsentligt element i vejledningsforløbet for de studerende. Eksempelvis genfandt vi forventningen om godkendelse før aflevering $\mathrm{i}$ en større spørgeskemaundersøgelse, som vi i Pædagogisk Center Samfundsvidenskab (PCS) gennemførte på Københavns Universitet (Harboe og von Müllen 2006).Vi spurgte 250 specialestuderende på Det Samfundsvidenskabelige Fakultet og Det Juridiske Fakultet og fik blandt andet følgende svarfordeling:

Spørgsmål: Skal vejleder godkende det fardige speciale for aflevering?

\begin{tabular}{|c|c|c|c|}
\hline & Ja & Nej & Antal \\
\hline SAMF & $66,9 \%$ & $33,1 \%$ & 136 \\
\hline JURA & $77,2 \%$ & $22,8 \%$ & 114 \\
\hline Total & $71,6 \%$ & $28,4 \%$ & $100 \% / 250$ \\
\hline
\end{tabular}

Kilde: Harboe og von Müllen 2006

Tabellen viser en iøjnefaldende (og bekymrende) stor enighed blandt de studerende om, at vejlederen skal godkende det færdige speciale før aflevering. Formuleringen af spørgsmålet i spørgeskemaundersøgelsen gi- 
ver ganske vist ikke mulighed for at tolke mere præcist, hvordan de studerende opfatter en sådan godkendelse, men som minimum kan vi konstatere, at der er en relativ omfattende og næppe ønskværdig forventning om godkendelse blandt de studerende, og at det derfor bør ekspliciteres både af vejleder og fra instituttets side, at der ikke udstedes garantier for bestemte karakterer eller lignende.

Men hvad siger vejlederne? I min analyse af klagesagerne fra KU og DPU læste jeg bedømmernes klagesvar, men kunne ikke konkludere klare tendenser ud fra dette materiale. For at fă viden om vejledernes syn på vejledningen kan man studere en aktuel undersøgelse, der er gennemført på Aarhus Universitet (Leth Andersen og Jensen 2006). Undersøgelsen har blandt andet interviewet vejlederne om deres syn på godkendelsesproblematikken, og disse resultater viser interessante paralleller til de nævinte resultater fra vores undersøgelser på KU. Eksempelvis citeres en vejleder i Århus-undersøgelsen for overvejelsen:

"Fordi hvis vejlederen læser det hele igennem, så føler den studerende, at nu har han en garanti. Og så făr han kritik [ved bedømmelsen], og så er der illoyalitet og problemer." (Vejleder, AU)

Århus-undersøgelsen er, så vidt jeg er orienteret, den til dags dato største danske kvalitative måling af vejledernes syn på specialevejledningen. Af relevans til denne artikels fokus på godkendelsesproblematikken bekræfter Århus-undersøgelsen fornemmelsen af, hvor uforholdsmassig stor en rolle den endelige bedømmelse spiller undervejs i vejledningsforløbet. Konsekvensen er, at mange studerende forsøger at få vejleder til at udstede garantier og så $\mathrm{i}$ øvrigt håber på, at vejleder fungerer som en slags forsvarer ved bedømmelsen. Det er en konsekvens, som mange vejledere har et temmelig ambivalent forhold til. På den ene side er de faglige refleksioner i centrum hos de fleste bedømmere, og her er den enkelte studerende blot én blandt mange andre studerende. På den anden side kan det være svært for (især) vejleder ikke at involvere sig personligt i de studerendes proces og produkt. Det sker ikke sjældent, at jeg møder sådanne alliancer mellem studerende og deres vejleder, hvor vejleder føler, at den endelige bedømmelse også fortæller noget om ham eller hende som fagperson. I Århus-undersøgelsen udtrykte en vejleder dette således:

"Jeg siger, »jamen du skal ikke være bange«, og »hvis $d u$ dumper, så dumper jeg også«. Det beroliger jo nogle af dem [...] Jeg ville føle det som et kæmpe nederlag, hvis jeg ikke skulle være i stand til at fă en specialestuderende igennem." (Vejleder, $\mathrm{AU}$ )

Samme pointe kom frem i mit fokusgruppeinterview om klagesagerne (Harboe 2005), hvor den ene vejleder fortæller om de problemer, en censor kan opleve, når bedømmelsen går imod den fællesforståelse og alliancebygning, der undertiden er etableret mellem vejleder og studerende:

»I almindelighed betragter jeg ikke vejleder som forsvarer. Men en af mine erfaringer er, at på RUC er det næsten umuligt at være censor, fordi der er virkeligt lavet alliancer mellem de studerende og lærerne netop i de lange psykologisk involverende processer, så făr man virkelig bank som censor, hvis man går ind og problematiserer, og det har jeg så gjort et par gange og også fået klagesager.» (Vejleder, DPU).

\section{Gode råd til studerende om godkendelsesfælderne}

- Forvent ikke, at vejleder kan eller vil blåstemple specialet før aflevering, men brug i stedet vejleder til at finpudse argumentationen for de valg, du har taget gennem specialeforløbet. Stil krav til din vejleder om, at han eller hun argumenterer for eventuelle vurderinger, ros eller ris.

- Forvent ikke, at vejleder fungerer som en slags forsvarer ved bedømmelsen.

\section{Gode råd til vejlederne om godkendelsesfælderne}

- Kom gerne med vurderinger eller ros, men konkretiser responsen til hvad og hvor præcist i teksten, du kommenterer. Så længe responsen er fremadrettet og kriteriebaseret, minimeres risikoen for, at den forveksles med blåstempling eller et løfte om bestemte karakterer.

\section{Gode råd til studienævnene og studielederne} om godkendelsesfælderne

- Præciser i studieordningerne, hvordan eventuelle formelle krav om godkendelse under vejledning skal håndteres. Er der tale om en forpligtende godkendelse, der binder de studerede (og vejleder) til at arbejde videre med en bestemt problemformulering eller et litteraturvalg, som de ikke kan ændre radikalt efter godkendelsen? Eller er det snarere en tilkendegivelse om, at specialets grundlag på et givet tidspunkt ser fornuftigt ud uden videre forpligtelse for hverken vejleder eller studerende?

\section{Adskillelse af vejledning og bedømmelse?}

I ovenstående tekstboks er der kort skitseret gode råd og løsningsmodeller med relation til de nævnte godkendelsesfælder. Et forslag med mere fundamentale ændringsperspektiver kan være helt at adskille vejledning og bedømmelse ligesom i ph.d.-bedømmelsesudvalgene. Jeg tænker her især på specialerne, men muligvis også BA-projekterne. En indlysende fordel er, at misforståelser om godkendelse og ros med ét slag vil være fjernet, når vejleder ikke er en del af voteringen. Den studerende vil ikke længere blindt og 
passivt kunne stole på vejleders vurderinger undervejs i forløbet og har dermed ikke mere gennemskueligt belæg for at håbe på, at vejleder fungerer som en slags forsvarer ved bedømmelsen. Vejleder tvinges på sin side til at være mere argumenterende i vejledningen, og teksten vil nødvendigvis komme mere i centrum, fordi den fungerer som mediet, der formidler de faglige diskussioner og pointer. Følgelig vil asymmetrien mellem studerende og vejleder antageligt minimeres, og vejleder vil formentligt komme til at opleve studerende, der stiller anderledes krav til vejleders engagement og pædagogiske kompetencer.

Adskillelsen af vejledning og bedømmelse vil muligvis ikke i sig selv nedsætte omfanget af klagesager, men der vil tænkeligt blive tale om andre typer af klagesager, der er mere fokuseret på selve bedømmelsesgrundlaget og -situationen. Der vil nok stadig være studerende, der bygger klagesager på en mere eller mindre veldokumenteret påstand om, at "vejleder sagde god for det", men det vil ikke være et gyldigt argument, fordi det bør være klart for alle parter, at bedømmelsen foregår ud fra almene kriterier, der er beskrevet og formidlet på institutniveau.Vejleder og censorinstitutionen vil på deres side blive tvunget til at eksplicitere bedømmelseskriterierne for de færdige opgaver, og feedbacken vil kunne blive sat i system. I dag hentes bedømmelseskriterierne i officielle tekster som fx studieelementets kompetencebeskrivelse i studieordningen og karakterbekendtgørelsens bemærkninger, men sådanne officielle tekster kan blive endnu bedre.

Ulemper ved adskillelse mellem vejledning og bedømmelse er bl.a. fordringen på censorstyringen, hvor censors kompetencer og indsigt $\mathrm{i}$ emner vil blive et endnu mere centralt forhold, end det er i dag.Vilkårlig udpegning af censorer, som stadig foregår visse steder, vil ikke være foreneligt med en adskillelse. Der mistes også muligheden for, at vejleder kan bruges som censors sparringspartner og påpege de originaliteter, der trods alt hyppigt forekommer i de afsluttende specialer. Det kan heller ikke udelukkes, at en adskillelse kunne animere nogle vejledere til både en mere engageret, men også en mere tilbagelænet indstilling til vejleder- opgaven. Derfor vil en adskillelse kræve klart bedre styrings- og kontrolinstrumenter, som fx systematiske evalueringer og obligatorisk pædagogisk efteruddannelse af både vejledere og censorer, for at regulere nogle af de tilsyneladende mindre forpligtende forhold i den adskilte vejledning og bedømmelse.

Samlet mener jeg imidlertid, at der er flere fordele end ulemper ved at adskille vejledning og bedømmelse ved det afsluttende speciale (og muligvis også ved BAprojektet). Især ser jeg en fordel $i$, at teksten kommer mere i centrum, og at de studerende i højere grad tør stille krav til vejleder (fx ud fra eksplicitte retningslinjer, tjeklister og lign.) uden frygt for konsekvenser ved bedømmelsen.Vejledningsforløbet vil herved kunne blive mere dialogisk og argumenterende, hvilket jo netop burde være kendetegnet ved universiteternes mission i form af videnstilegnelse og erkendelsesskaben.

\section{Litteratur}

Eksamensbekendtgørelsen af 31. august 2004

Giddens, Anthony (1997): Modernitetens konsekvenser (oversat til dansk af Søren Schultz Jørgensen). Hans Reitzels Forlag.

Leth Andersen, Hanne og Andersen, Tine W. (2006): Specialevejledning - rammer og roller. Forlaget Samfundslitteratur (under udgivelse)

Harboe, Thomas \& von Müllen, Rikke (2006): De studerendes forventninger til specialevejledning - en spørgeskemaundersøgelse på Det Samfundsvidenskabelige Fakultet og Det Juridiske Fakultet. Københavns Universitet

Harboe, Thomas (2005): Akademisk Opgavevejledning - en handlingsorienteret analyse of 51 udvalgte klagesager. Masterafhandling. Danmarks Prdagogiske Universitet

Harboe, Thomas (2000): De studerendes forventninger til specialevejledning - en sporgeskemaundersøgelse på samfundsvidenskab og humaniora. Københavns Universitet

Pittelkow, Ralf (2001): Det personlige samfund - Et portrcet af den politiske tidsånd. Lindhardt og Ringhof.

Rienecker, Lotte; Harboe, Thomas; Stray Jørgensen, Peter (2005): Vejledning - en brugsbog for opgave- og specialevejledere på videregående uddannelser. Forlaget Samfundslitteratur

Rienecker, Lotte og Harboe, Thomas (2004): Studerende med behov for vejledning og støtte - Hvidbog med handlingsforslag til KU-studerende, undervisere, institutter, studievejledninger, studieadministration, vejledninger/rådgivninger angående studerende med behov for vejledning og støtte. Københavns Universitet 